\title{
SPIRITS, POWER AND THE POLITICAL IMAGINATION IN LATE-COLONIAL GABON
}

\author{
John M. Cinnamon
}

\section{AN ANTI-FETISH MOVEMENT COMES TO NORTH-EASTERN GABON}

In north-eastern Gabon during the years prior to independence, religious and political imaginations converged in ways that continued to shape understandings of social and political history half a century later. In 1955, a ritual specialist named Emane Boncoeur (or Emane Nyangone) arrived in the town of Makokou from Souanké in Moyen-Congo to lead an anti-fetish movement. ${ }^{1}$ Emane came armed with two powerful spirits, Mademoiselle and her husband or brother Mimbare (also called Jean or Jean-Baptiste). ${ }^{2}$ Emane toured the countryside, especially the Fang-speaking villages to the west of the Ivindo River (see Figure 1). He performed ceremonies, identified sorcerers and compelled villagers to turn over their power objects: protections, medicines, ancestor relics, harmful 'fetishes'. Those who resisted were struck or seized by Emane's spirits in nocturnal visits, and subsequently fell ill, went insane, or died. Emane stopped at the district boundary 80 kilometres west of Makokou; others carried the movement to points beyond. This movement has shaped historical memory profoundly; it also illustrates how Fang speakers from the region mediate between visible and invisible powers, and how they understand their marginalization from regional and national politics. At the same time, the direct intervention of white 'spirits', while building on previous anti-sorcery movements such as $n g i$ (or $n g i l$ ), ${ }^{3}$ also

JoHn M. CINNAMON teaches Anthropology and African Studies at Miami University (Ohio). He has worked extensively in Gabon and Cameroon and has published on the historical anthropology of equatorial Africa, the rain forest environment, and the influence of missionary ethnographers on professional anthropology. Currently he is studying the history of the latecolonial and post-colonial religious imagination in Gabon. In 2011-12 he is a Fulbright Scholar at the Ecole Normale Supérieure in Yaoundé. Email: cinnamjm@muohio.edu

${ }^{1}$ Emane was one of a number of ritual experts who introduced Mademoiselle to Gabon. Joseph Tonda (2002: 65-75) examines the case of Zoaka-Zoaka, who encountered Mademoiselle and John the Baptist in the Upper Ivindo region in 1954. Zoaka-Zoaka operated as a 'fetish finder' and, later, a healer near his hometown of Mékambo. He toured the villages and towns of OgoouéIvindo, Haut-Ogooué and Moyen-Congo.

${ }^{2}$ Earlier accounts of Mademoiselle (Digo 1956; Weinstein 1966; Fernandez 1982) have focused almost entirely on the female spirit. In interviews, Gabonese insist, however, on the importance of the male spirit. Tonda $(2000 ; 2002)$ refers to Mademoiselle as a spirit who carried out what he calls the 'work of God', linked to two forms of hybrid, ambivalent, interconnected capital - the 'capital of God' and the 'capital of sorcery' (Tonda 2002: 64).

${ }^{3} \mathrm{Ngi}$ or $n g i l$ was a powerful 'anti-witchcraft cult' that spread in various iterations throughout northern Gabon, Equatorial Guinea, and southern Cameroon during the upheavals of the late pre-colonial and early colonial periods (Fernandez 1982: 222). Ngil provided powerful protection against sorcerers who lived with one foot in the terrestrial world and the other in the intermediary, extra-terrestrial world (Aubame 2002: 141). The ngil leader (nnôm ngil) also lived astride these 
marked a significant but paradoxical innovation that harnessed white power to weaken Africans. ${ }^{4}$ Since the 1950s, Mademoiselle and Mimbare have been incorporated into a range of initiation and healing practices, including Mimbiri, Mimbalé, and Bwanga. During ceremonies initiates consume the powerful forest psychotropic, iboga, to voyage to the spirit world where they encounter the spirits. East of the Ivindo and in northern Gabon, Mimbalé and Ndéndé practitioners listen to Mimbare and Mademoiselle during consultations or ceremonies through wands they have received mystically during their initiations.

Mademoiselle and Mimbare appear primarily to those who have cultivated 'occult vision': ritual experts, initiates, those with 'open heads', and also those they punish. A 'Euro-African' spirit, usually described as French, white and comely, with flowing hair and a long gown, Mademoiselle embodies mysterious European power put to use by some Africans against others. Some practitioners associate her with the Virgin Mary, Mary Magdalene, or Mami Wata, while Mimbare is linked to John the Baptist, sent to purify the land. In some accounts, however, Mademoiselle is the spirit of Emane's sister, sacrificed to give him his extraordinary powers. These differing representations of Mademoiselle suggest that equatorial Africans experience, narrate and speculate about the invisible world in a variety of contradictory ways that also inform, as explored here, divergent political imaginings.

Colonial records cite stories that Emane received the spirits from a Frenchman in Cameroon in order to combat evil and sorcery (Tonda 2002: 65). Others have gained access through direct revelation or initiation and apprenticeship, usually preceded by a call to heal via spirit visions and physical or mental illness. Mimbare and Mademoiselle are thought to have communicated directly with Emane-appearing to him at night, speaking to him during fetish-finding tours, and by some accounts writing revelatory information in the book he carried, the latter symbolizing the power of European bureaucratic knowledge, which his movement ritually reinforced.

Decades later, Fang speakers from north-eastern Gabon recalled Emane's movement with vivid ambivalence. Women, in particular, are convinced that by ridding the country of powerful sorcerers Emane left a lasting positive legacy. Yet - as argued here-many, including devotees, believe that he and his spirits permanently weakened the country by robbing people of their power objects at precisely the moment they needed all their force to compete for power in the nascent Gabonese state. Emane's tour coincided with the growing national

two worlds and could see 'the casters of sorcery and strike them at the very moment they commit [ed] their misdeeds' (p. 145). Aubame concludes that $n g i l$ was 'more political than religious' in the measure that it sought 'to maintain order and security of citizens, both in their persons and their goods' (p. 147). Laburthe-Tolra (1985: 353, 364) notes that ngi members had the power to neutralize sorcery attacks and the ruthlessness to hunt down, unmask, punish and kill sorcerers. At the same time, ngi, like Mademoiselle, 'reinforced inequality' and was susceptible to misuse. Fernandez (1982: 225) characterized the Ndéndé movement - an outgrowth of Mademoiselle that reached Oyem in late 1957 - as a mid-twentieth-century version of $n g i$.

${ }^{4}$ Florence Bernault (1996: 187-95) writes of an Ngol cult that, emerging in the 1940s, drew on the symbolism and power of Général de Gaulle, who had been converted into a 'popular fetish' by his French supporters. The Ngol cult served as an 'anti-sorcery movement' and allowed colonial subjects to use white power for their own ends while in no way seeking 'to destroy colonial power, even symbolically' (p. 190). 


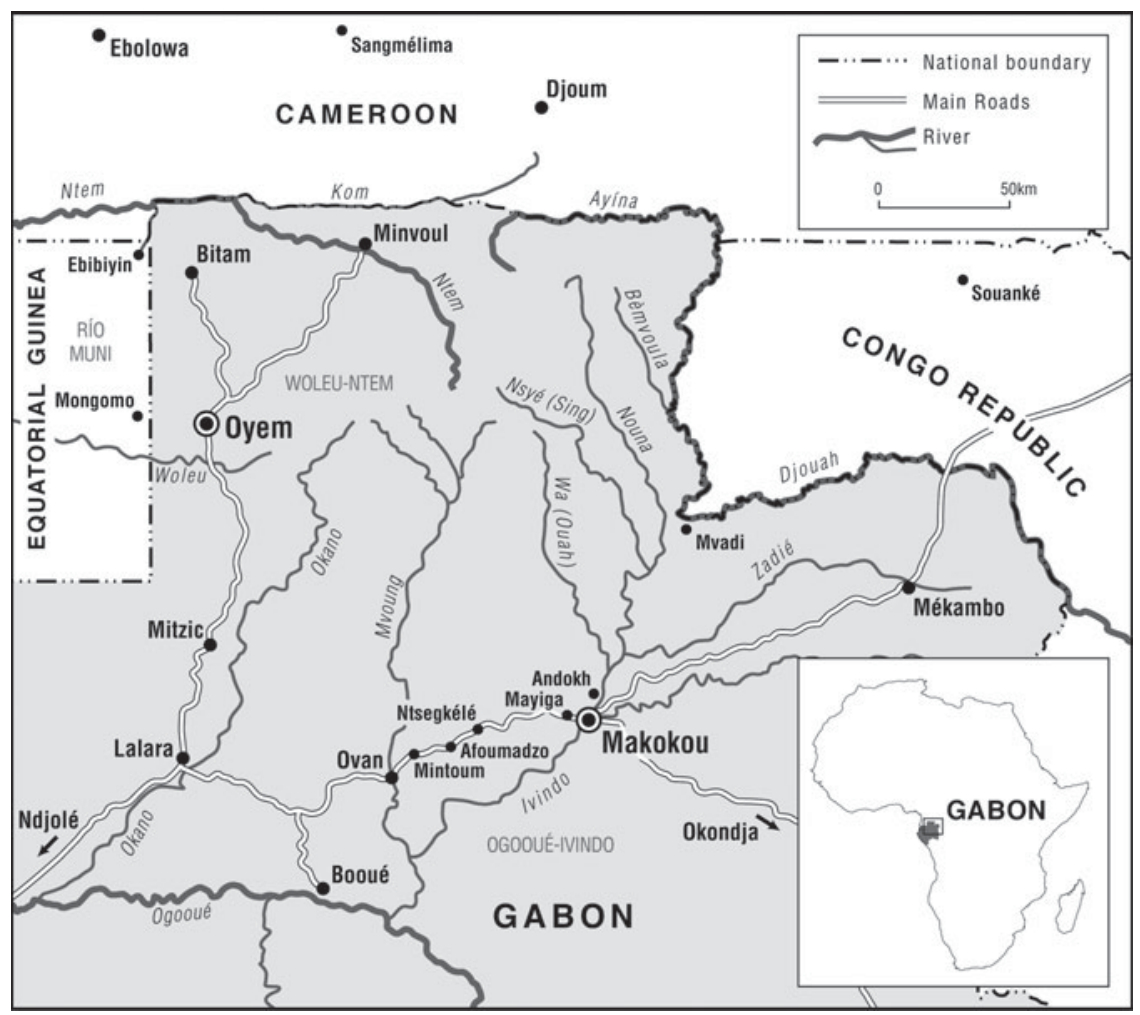

FIGURE 1 Northern Gabon in the 1950s: major rivers, roads and administrative centres

political rivalry between député Jean-Hilaire Aubame and the man who would become Gabon's first President (1961-7), Léon M'Ba. Emane's arrival also played into regional ethnic and political rivalries. In the 1952 Territorial Assembly elections, the Fang candidate, Marc Essia-Nsomore, had lost to Paul Zembote, a Kwélé speaker originally from Mvadhi on the Upper Ivindo River. Three years later, following Essia-Nsomore's death, territorial councillor Zembote invited Emane to come to Gabon to combat sorcery and fetishes, a passage remembered as particularly devastating in the Fang villages that had supported Zembote's rival. Emane's visit was also authorized and closely monitored by colonial officials in Makokou and Libreville, whose chief concern was maintaining order and control (Cinnamon 2002). Thus both Gabonese politicians and colonial administrators were intimately involved in the tour of Emane and his spirits. While the goal here is to understand how Gabonese viewed this anti-sorcery movement 'from below', the movement itself originated and was sanctioned from above.

The present article brings together discussion of late colonialism and changes in northern Gabonese spirituality to highlight struggles in rural communities over access to a central government that included both elected Gabonese officials and 
colonial administrators. It proposes an alternative reading of 'grassroots' political understandings that departs from studies focused on political parties, unions and international politics. Both villagers and regional political elites have shared very similar understandings of the invisible dimensions of power. As invisible forces, Mademoiselle and Mimbare ushered in a new political era, characterized by competition, loss and marginalization. Narratives about Mademoiselle and Mimbare thus provide important insights into a Gabonese political imagination ${ }^{5}$ and make close connections between the 1952 Territorial Assembly elections, the coming of Emane and Mademoiselle in 1955, and the marginalization of OgoouéIvindo Fang speakers from national political power. Villagers express their disillusionment through moralizing stories that attribute their disempowerment, neglect and resistance to occult human agency (Ngolet 2000; Mba Ndzeng 2006).

\section{SPIRIT MOVEMENTS, OCCULT POLITICS, LATE COLONIALISM}

In its movement across the landscape, the Mademoiselle movement paralleled other late-colonial anti-sorcery movements. The Atinga anti-witchcraft movement, for example, arrived in south-western Nigeria in 1950-1 as part of a 'strategy of political and economic empowerment by a rising commercial elite' during a period of increased cocoa production and economic growth (Apter 1993: 113). In Moyen-Congo in 1953, Lassy Simon Zéphirin founded an anti-sorcery/ anti-fetish movement to cleanse his region of 'its diabolical practices' (Hersak 2001: 621; Soret 1959: 98).

In its complex interactions with state politics and turn to healing, Mademoiselle also resembled other equatorial African spirit movements. In post-colonial CongoBrazzaville in 1973, the Mvulusi therapeutic movement arose under Ma Meno Véronique, who began her career by entering into trance and accusing her clan chief of 'eating people'. Later, she established a healing practice in Pointe Noire that drew on Vili and Judaeo-Christian mythological and metaphysical frameworks, including spirits and holy water (Hagenbucher-Sacripanti 1992: 66-70). After her death in 1977, her followers navigated complex political relations, first with the single-party Marxist state, and, later, with Congo's turbulent multiparty system (Hagenbucher-Sacripanti 2002). One politically active adherent 'insisted on the inseparability of the political and the religious' (2002: 526).

I situate this article at the intersection of two bodies of scholarship in Africanist anthropology and history. The first has to do with the close relation between political power and the invisible, politicians and spirits, politics and the occult (see, for example, Geschiere 1997; Niehaus 2001; Schatzberg 2001; Ellis and Ter Haar 2004; Ashforth 2005). Much of this literature emphasizes the resurgence of occult power in post-colonial Africa in response to global modernity and

\footnotetext{
${ }^{5}$ By political imagination, I refer to what Jean-François Bayart (2005: 233) has called 'the constitutive imagination' that 'plays a central role in the formation of the state, and more generally in the production of politics'. For Bayart, the political imaginaire draws on 'a plurality of cultural repertoires' including materiality and political economy; it is characterized by heterogeneity, ambivalence and 'interaction between the past, the present, and a projected future' (Bayart 2005: 105, 163, 137, 226). See Mbembe (2001: 145), Crais (1998: 53; 2002), Masquelier (2001: 269-70) and Eaton (2006: 45, 69) for discussion of the political imagination in Africa.
} 
the occult violence of millennial capitalism (Comaroff and Comaroff 1999; 2000). As Florence Bernault (2009b: 774) has put it, 'modern witchcraft has become the dominant paradigm in the studies of African religious beliefs'. Recently, Terence Ranger (2007: 274-5) has argued that many of these studies over-generalize the occult. Instead, he argues, 'occult phenomena need, like all others, to be situated in their own particularity' (ibid.: 277). In the particular case presented here, that of north-eastern Gabon in the years immediately preceding independence, Mademoiselle and Mimbare loomed at the heart of political processes.

The second body of scholarship assembles the burgeoning number of detailed historical studies of late colonialism, nationalism and decolonization across Africa. Together these studies have sought to move beyond emphasis on political parties, African elite males, mass political mobilization from above, and wars of independence. Revisionist studies have elucidated the roles played by women political activists in the production of nationalism in Tanganyika (Geiger 1996; 1997), the intersections of popular music and nationalism in late-colonial Luanda, Angola (Moorman 2008) and the decisive influence of 'grassroots ethnic, class, regional, and gender alliances' as well as 'low-level civil servants and trade unionists' in Guinea's move to independence (Schmidt 2009: 23; 2005). Most of these studies, however, with the exception of the growing number of accounts of independent and Pentecostal African churches (for example, Maxwell 2006; Kirsch 2008), downplay spiritual and invisible domains of power.

Exceptions include late-colonial Dar es Salaam, where rumours circulated of blood-sucking European vampires (mumiani) and their African assistants who extracted the blood of victims they had abducted 'to make medicines that would further increase their powers' (Brennan 2006: 392-3). Such rumours expressed relations between urban citizens, nationalism and economic inequality, and led to a 1959 riot in Dar es Salaam. While TANU nationalists deplored the 'superstition' and violence, they opportunistically borrowed metaphors of 'blood sucking' to denounce colonial exploitation and inequality (Brennan 2006; 2008). In the Cameroon Grassfields during and after the violent transition to independence, village politics, nationalism, failed revolution, spirituality and 'the influence of the invisible world on political processes' intersected. According to one resistance fighter, the 'failure to uphold a spiritual alliance' between a multi-dimensional non-Christian God and man-an alliance mediated by ancestors and spirits-caused 'the violence of the independence war in the Grassfields region' (Terreta 2005: 75-7, 98). Finally, in pre-colonial, colonial, and post-colonial Mozambique, sorcery and the invisible have been worked and reworked continually to inform governmentality and political power (West 2005).

Of course, not all people in Gabon make explicit connections between Mademoiselle and politics. In the Ogooué-Ivindo, Kwélé speakers, who vie for power with Fang and Kota, admit that the removal of their power objects in 1955 left them in a weakened, albeit purified state, but tend to depoliticize the episode. As one Kwélé man put it, 'There had been many deaths in our canton due to sorcery and medicines.' People asked territorial councillor Zembote to call Emane Boncoeur 'to remove the medicines'. ${ }^{6}$ In the northern Woleu-N'Tem region, where Mademoiselle also arrived to remove fetishes, she was not directly involved

\footnotetext{
${ }^{6}$ Interview, Joseph Bapasse, Libreville, June 1996.
} 
in state politics (Fernandez 1982: 215-40). ${ }^{7}$ Even before independence, the spirits were incorporated into healing practices and initiation religions such as Bwiti and Mimbiri, where, again, they were connected less directly to state power. ${ }^{8}$ Moreover, both villagers and urban-based intellectuals originally from northeastern Gabon are eminently capable of retracing their version of regional and national political history without evoking invisible power. They speak of big-man political competition, winners and losers, and regional marginalization. Late colonialism initiated new forms of accumulation by Gabonese politicians while holding out the false promise of independence (and the paradox of disempowerment) to rural villagers.

Key stated goals of Emane's 1955 mission to Gabon were to combat sorcerers (pl. bayəm in Fang) and to remove harmful mabyan: power objects, medicines, fetishes. The problematic term 'fetish' and its derivations are the product of a complex history in equatorial Africa that dates back at least to the fifteenth- and sixteenth-century Portuguese mercantile encounter with West and Central Africans (Pietz 1985, 1987, 1988; Tobia-Chadeisson 2002). As elsewhere in equatorial Africa (MacGaffey 2000; Bernault 2009a, 2009b), the term fétiche has slipped into Gabonese French and refers to bivalent power objects that may protect and heal or provoke blockage, misfortune, illness and death. Of course, post-colonial 'fetish governments' - authoritarian systems that imagine power as a sacred but violent object invested in the autocrat and his agents (Mbembe 2001: 111)-would not have materialized ex nihilo. In Gabon, the magical political battles of the 1950s built on earlier conceptualizations of power - 'regimes of fetish' (Bernault 2009a). These changed under the weight of the colonial situation while foreshadowing the fetishization of political power in the post-colony.

Variously represented as unseen forces, spirits (minsisim in Fang), medicines (mabyay), or miracles, Mademoiselle and Mimbare embody a fundamental ambiguity, widely noted in Equatorial Africa, between protective and harmful forces, between healers and sorcerers, between protective and harmful medicines. ${ }^{9}$ In late-colonial Gabon, a similar ambiguity existed when it came to medicines, spirits, ritual experts, sorcerers and politicians; all could operate for good or ill. This ambiguity lies at the centre of conceptualizations of power and political culture, including state politics. Mademoiselle and Mimbare, as new invisible forces in the region, ushered in a new political era.

I now turn to a number of narratives (recorded between 1988 and 2005), beginning with an interview with the late territorial councillor Paul Zembote that underscores the relation between Emane's 1955 anti-fetish tour and the latecolonial political imagination. A second narrative suggests how Emane and his spirits continue to permeate popular consciousness; it evokes not only the violent confrontations between the spirits and those who resisted them, with the

\footnotetext{
${ }^{7}$ Fernandez (1982: 228) does note in passing, however, that 'Among Fang of northern Gabon, the struggles of the 1950s between the two political parties - the BDG and the UDSG - were often cast in the idiom of witchcraft.'

${ }^{8}$ Of course, as purveyors of power from the invisible realm, ritual experts are frequently sought out by ambitious politicians at all levels.

${ }^{9}$ In Kongo Political Culture, Wyatt MacGaffey captures the ambiguous ties between kindoki ('witchcraft') and the power of chiefs. Among the Kongo, 'witchcraft' served as a morally ambiguous source of power used by both evildoers and chiefs (MacGaffey 2000: 12-13).
} 
imperative of submission, but also the spirits' involvement in healing practices. I then turn to several interviews: with a former député; a village chief and a party official; a retired registered nurse who accompanied Emane's delegation; and a village elder. All of these situate the coming of Emane squarely within the framework of local and regional political rivalries. It is here that the convergence of spiritual and political imaginations is most evident. A final section moves beyond Emane and Mademoiselle as political origin myth to trace connections between regional politics in the 1950s and an emerging national political imagination. Here, village elder Jean Nzeng explains what he calls 'the paths of politics' as well as his understanding of multiple political beginnings that have culminated in local marginalization and frustration. Together these narratives suggest the partial contours of a masculine political imagination, shared by both villagers and regional political elites, that includes but is not reducible to the invisible.

\section{MADEMOISELLE AND THE POLITICAL IMAGINATION IN OGOOUÉ-IVINDO: 'I, TOO, WAS AFRAID....'}

The first narrative, based on a 1990 interview with former territorial councillor Paul Zembote, suggests the close connections between 'fetishes', spirits, politicians, the colonial administration and Emane Boncoeur's arrival. Zembote was Bekwil (also Kwélé, Bakwélé) born in c. 1915 at Mvadhi, a village and colonial post on the Ivindo River. Zembote attended primary school in Mvadhi until the post (and school) closed in 1929. He then went to Makokou where he became an interpreter/scribe, and later an assistant nurse, before entering politics. Fang elders spoke of Zembote with considerable resentment, intimating that he had summoned Emane and his spirits in 1955 to weaken them. When we met, I (tactfully) asked him about Emane Boncoeur. While calling attention to his role as territorial councillor and, therefore, as a broker between the colonial administration and the people, Zembote, whose response I summarize here from field notes, de-emphasized the political:

In 1955, Zembote represented Ogooué-Ivindo as territorial councillor. At that time, he said, 'People were fetishers - among the Bakota, the Fang, it was the same thing. People complained ... [and] were hunting down fetishers. Custom was bad. There was jealousy. Even the groundnut fields - people had medicines against other people's plantations....'

People in Mvadhi told Zembote that there was an Ndzem (Njem) from Congo, Emane Boncoeur, who removed fetishes. Zembote wrote to Souanké, and, two months later, Emane agreed to come. He came to Mvadhi, where he removed the fetishes - 'he did not want them'. ${ }^{10}$ People told the administration that Emane made fetishes. ${ }^{11}$ When Emane

\footnotetext{
${ }^{10}$ Zembote adds that a Mme Mariama made fetishes that people used even in north-eastern Gabon. He said that she sold these fetishes from Bordeaux, France. Fernandez (1982: 234) also writes about mail-order charms and pulp-magic literature sold from France during the late 1950s.

${ }^{11} 1955$ administrative reports indicate that people made no complaints to the authorities about Emane's visit: 'The fetisher Emane Boncoeur, object of preceding report, continues his tour in the Makokou District. One of his aides visits the villages on the Mékambo road. This presence, sought after by the villagers, has not at present, drawn any unfavourable reaction. I have asked
} 
arrived at Makokou, administrators held Zembote responsible. 'You're the one who brought him.' Zembote wrote to Governor Digo, to explain the situation and justify his actions.

Emane's work began at Andokh and Mboula, Fang villages on the right bank of the Ivindo, just upriver from Makokou. 'He filled baskets with fetishes. ... Emane danced all night, until Mimbalé [Mimbare] came. Then Emane said, "You, go get what you have in your house!" People left trembling. [They brought] skulls and bones.'

Emane put the fetishes into holes, reciting a prayer over them. 'He who wants to renew these will have problems.' Afterwards, he burned them, leaving two pickets in the ground to mark the place. Then he said, 'If you go out as a vampire to see what is in the hole, you'll die.'

Ivindo District Administrator Leray came. An inspector came out from Libreville to investigate. Emane explained how he used the fetishes while Zembote translated.

'Who showed you this fetish?'

He said that it came from a white man who had been in Djoum (in Southern Cameroon). The white man had removed the fetishes in Djoum. Emane went out at night to see the fetishes.

People asked Zembote about his interest in this affair.

He said, 'I am here, I am Bakwélé, Bakota, Fang.' Thus, he accounted for his 'interest' by underlining his own membership in the broader, multi-ethnic political community. Moreover, at the time he, too was 'afraid of fetishes'.

Léon M'Ba, who would become Gabon's first President, wasn't pleased. Emane had sent people to the Woleu-Ntem to remove byeri [ancestor relics]. ${ }^{12}$

Emane said, 'In three or four years, there will be silence. Except for those who go to look in the hole.' Zembote, recalling Emane's intervention, concludes that, 'He asked for nothing ${ }^{13}$ and has since died, replaced by another. We Christians ask the Father of the Holy Water to chase away the bad spirits.'14

As Zembote explained it, he was merely carrying out his duties as a conscientious public servant, protecting his distraught constituents-and himself - from the menace of fetishes. Zembote mentioned other anti-sorcery associations (Mungala, Benjie, Njobi) but dismissed these as ineffective or evil. This recalls the ambiguous potentialities of anti-sorcery movements, including Mademoiselle. Moreover, Zembote points to a close relationship between sorcery, anti-sorcery and Christianity (Tonda 2002; 2005). His last comment invokes God the Father and Holy Water, but his preceding discussion suggests that these were not enough to neutralize sorcery, 'bad spirits' and fetishes. As an African Christian, Zembote thus called on an African ritual expert (Emane) who used two Euro-African spirits (Mademoiselle and Mimbare) in African ways to promote an imported religion at the expense of African ritual practices.

the Chefs de Districts to exercise a constant surveillance and to inform me of any observations they are able to make' (Archives Nationales du Gabon (ANG), F. P. No. 529, 'Rapport de la Tournée effectuée dans la Region de l'Ogooué-Ivindo du 18 au 25 Mai inclus par le Chef de Region', Ph. Berge). See Cinnamon 2002.

${ }^{12}$ Fernandez (1982: 234) also notes that the Gabonese government of Léon M'ba was reticent about the Ndéndé movement in Oyem.

${ }^{13}$ According to the above-cited government report on Mademoiselle (Digo 1956), Emane collected money from those who possessed power objects: ' 200 francs from each [person] who had human skulls, from 50 to 75 francs from all other holders of fétiches, and 25 francs from each big person in the district of Makokou'.

${ }^{14}$ Interview, Paul Zembote, Makokou (Quartier Zoatab), 7 April 1990. 
Emane's anti-sorcery was particularly effective because he had obtained his force from a white man in Southern Cameroon. Tonda (2002: 65), citing a 1956 colonial report on the Mademoiselle anti-fetish movement, identifies this European as a Public Works agent named Benoît. After having asked Emane for hair and nail clippings and 5,000 francs, Benoît gave him a booklet and a phial of perfume by which he beckoned Mademoiselle to help him to combat harmful fetishers. This suggests the long-distance pathways along which anti-sorcery movements and other practices travelled. A white man had brought Mademoiselle from Europe to Djoum, a Bulu-speaking town in Southern Cameroon. Emane had received her there, and carried her back to Souanké, an Njem- and Bekwil-speaking town in the Moyen-Congo. From there he conveyed her to Mvadhi, Zembote's village on the Gabon-Moyen-Congo border, and then on to Makokou, a Fang-, Kota-, and Bekwil-speaking town, and the Fangspeaking villages west of the Ivindo River.

Finally, Ndéndé, a Kota or Chiwa speaker from near Ovan, took the movement to the regional capital, Booué, and to Okandé villages south of the Ogooué River. ${ }^{15}$ It is to Ndéndé that Zembote probably referred when he said that Emane had sent people to Woleu-Ntem to remove Fang reliquary objects. At the same time, Zembote's statement that Léon M'Ba (then Zembote's colleague in the Territorial Assembly and, as of November 1956, mayor of Libreville) was unhappy may refer to widespread speculation that M'Ba's power came from the ancestors and other invisible sources. M'Ba might have seen Ndéndé's movement as a threat. Of course, Ndéndé's work in the vicinity of Oyem is well documented and remains etched in the popular imagination (Weinstein 1966; Fernandez 1982; interviews in Oyem and Minvoul 2005). North of Oyem, villagers thwarted Ndéndé's arrival (Weinstein 1966: 54). ${ }^{16}$ Here we have a transnational antisorcery movement that inspired widely varying local and regional or even ethnic reactions and interpretations.

According to Zembote, Emane in his war on fetishes used or sent out Mademoiselle and Mimbare on night-time search-and-destroy missions, reminiscent of vampires who also go out at night in vampirisme ( $\mathrm{ggbal}$ ). Emane succeeded primarily because he had access to more powerful invisible forces. Zembote, for his part, tells us that he, too, was afraid of fetishes. He directed Emane to Kwélé villages on the left bank of the Ivindo and then across the river to the villages of his Fang-speaking rivals. Perhaps Zembote perceived Emane as a means of protecting himself from village-based 'levelling mechanisms', thereby enabling him to accumulate power in the emerging realm of national politics (Geschiere 1982; 1997). The political realm offered unprecedented opportunities for some while also creating new social inequalities. Zembote downplayed power politics, but Emane's spirits not only protected Zembote's constituents - they also attacked them, forcing them to submit.

\footnotetext{
${ }^{15}$ See Tonda (2002: 66); Digo (1956). Ndéndé's family in Kombani spoke especially of his work among the Okandé across the Ogooué River from Booué (Interview, 15 January 2005).

${ }^{16}$ Some elders concluded that Ndéndé did not carry his spirits beyond Oyem, while others said that he worked as far as the border between Oyem and Bitam before he was turned back (Interviews 2005, 2008).
} 


\section{'HE BROKE THE STONE WALL WITH HIS FORCE'17}

Decades after the passage of Emane through the Fang-speaking villages of Ogooué-Ivindo, both Emane and his spirits remained rooted in popular consciousness. Efaghe-Akare Basile, not born until 1963, eight years after Emane's visit, spoke of Emane and his spirits with easy familiarity. He also knew which healers continued to use Mimbare and Mademoiselle in their work. Mimbare was a spirit who befriended those who 'had nothing' and attacked sorcerers and people with evu. Efaghe knew very well that Emane Nyangone had brought Mimbare from Souanké. 'When Emane Nyangone came to Makokou,' he noted, 'the people built a stone wall. He broke it with his force. People died.' This of course hints at mystical battles between Emane and the sorcerers whose medicines he sought to remove. ${ }^{18}$ Efaghe underlined Emane's force and illustrated how Mimbare and Mademoiselle have become part of Gabon's postcolonial spiritual landscape, linked to healing. It was also Efaghe who, early in my fieldwork, first called my attention to the importance of Mademoiselle in the local imagination. Efaghe described how Emane carried out his work:

When Emane Nyangone arrived in a village, he lined up everyone. He made some people kneel on stones. With his magic baton, he revealed those who had skulls, snakes, and people's fingers [relics]. He called to the person; the person came and knelt. If you have anything, you must tell him. Otherwise, you are going to die. He tells you to go find it in your house or in the forest, and you bring it. Before taking it, he rubs you with his Mimbare perfume [mbon Mimbare]. After he has rubbed you, he puts [your fetish] in his basket....

If you try to hide it, Mimbare attacks you and asks you to give it to him. He can slap you and you go insane. It is he who makes people go crazy here, only he. He comes at night in a dream. Even if you want to go out as a vampire and he is at Makokou, he has already seen you.

When Emane had finished his work he chose people from the village to carry what he had collected. Sometimes there were two or three full baskets. After having removed the fetishes he would go to each end of the village. He planted an abam bush. Mimbare also

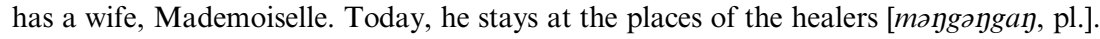
.. $^{19}$

Without making overt political connections, Efaghe underlined the colonial imperative of submission to superior force. People were compelled to relinquish their medicines - whether harmful or beneficial - or face drastic consequences. After Emane's visit had moved on to the next village, the villagers remained behind, protected only by the terrible force that had subdued them in the first

\footnotetext{
${ }^{17}$ Efaghe-Akare Basile, informal discussion, Ntsengkélé, 5 June 1988.

${ }^{18}$ Along similar lines, Emane Ebome Raymond (Mayiga, 6 April 1990) noted that when Emane arrived at Afoumadzo, on the Booué road, after having removed many fétiches in the previous village (Bissobinlam), he himself fell ill. Had he been weakened by his 'night battles'? According to interviews recorded in Minvoul and Oyem in 2005, Ndéndé and his followers also faced invisible walls erected by sorcerers (bəyəm), that is, those who possessed an active evu or evus and nefarious medicines.

${ }^{19}$ Efaghe-Akare Basile, informal conversation, Ntsengkélé, 5 June 1988.
} 
place. Later, healers gained access to the spirits and used them not only to remove fetishes but to consult patients and diagnose illnesses.

\section{THE RISE AND FALL OF MARC ESSIA-NSOMORE}

In the regional political imagination, Marc Essia-Nsomore embodied the hopes and disappointments of Fang speakers. He is remembered as a great intellectual and man of book learning capable of delivering his Ogooué-Ivindo brethren to the political promised land. In the end, Essia lost the 1952 election, died of malaria two years later, and could not deliver. Without directly accusing Zembote of complicity in Essia's death, ex-député and government minister Nze ThomasDydyme suggested close conceptual and even causal links between Zembote's 1952 election victory, Essia's death, Emane's arrival, subsequent disempowerment of Ogooué-Ivindo Fang, and the quashing of their legitimate political aspirations. Nze also provided a sketch of Essia's truncated political biography. It is a tale of lost potential and serves as an allegory of the region's perceived political marginalization in post-colonial Gabon. ${ }^{20}$

Essia began his education around 1930 at a school run by the military administration in Makokou. After its transfer to civilian administration in 1936, Essia continued at the new Protestant Mission school at Alarmintang, on the outskirts of Makokou. ${ }^{21} \mathrm{He}$ finished primary schooling at Angomo on the lower Ogooué in 1941, and earned an additional certificate in 1943. He then taught at the Mfoule Protestant Mission school in Oyem (1943-5) before being reassigned to Ovan, 100 kilometres west of Makokou, where he opened cours moyen - the last two years of the primary-school cycle. ${ }^{22}$

Electoral politics came to Ogooué-Ivindo in the immediate post-Second World War years. In 1947, Essia was still too young to present his candidacy for the Territorial Assembly elections. A former abbé, Augustin Essone Ekoume from the Moyen-Ogooué region, represented the Ogooué-Ivindo from 1947 to 1952. The fact that this territorial councillor came from outside the region suggests the relative isolation of Ogooué-Ivindo and the late arrival of electoral politics. When Essia ran in 1952 he lost to Zembote. According to Nze, the Protestants had not wanted Essia to leave teaching and intervened with colonial administrators, who in turn saw him as less malleable than Zembote. ${ }^{23}$ Essia was furious and tried

\footnotetext{
${ }^{20}$ Nze-Emane Thomas-Dydyme, Interview, Libreville, 24 June 1995.

${ }^{21}$ Later the Protestant Secondary School at Alarmintang was named after Essia-Nsomore, thus anchoring his name in official memory.

${ }^{22}$ Nze-Emane Thomas-Dydyme was Essia's pupil in 1950-1. That pupils could not complete primary school in the region until after the Second World War underlines the region's 'lateness' when it comes to national politics.

${ }^{23}$ Bernault (1996: 96-100) writes of widespread 'electoral manipulations' by colonial administrators in Gabon and Moyen-Congo during the late 1940s and early 1950s. Government political reports from Makokou in 1952 suggest possible tampering on the part of the administration in the outcome of the elections. A monthly political bulletin from March announces that Essia has been elected, having defeated Zembote. The July 1952 bulletin, however, announces the arrival of Zembote, the new representative councillor of Ogooué-Ivindo, from his former post in Lastoursville. The report notes that 'this election was poorly received by the Fang', and that Essia had sent a complaint to Brazzaville (ANG, Répertoire MKK, Carton
} 
to leave the Mission before being reassigned to Oyem, where he died in 1954. His death spelled a double loss for the Fang of Ogooué-Ivindo. First, their candidate lost the elections which would have assured them more direct representation in state affairs; then they lost their candidate. ${ }^{24}$

In the popular imagination, the winning candidate, Paul Zembote, was somehow linked to Essia's death. Only occult forces could have killed a man such as Essia, and Zembote feared vengeance. According to Nze, Zembote had said that the Fang were trop sorciers. He sent for Emane at Souanké to come and remove all of the medicines in Makokou. 'Essia had been beaten.' As Nze put it:

The fetishes were removed. He [Emane Boncoeur] did what he was able to do. Essia died in these conditions. Efa-Ayong [Essia's partner in the 1952 election] had died in Lastoursville in 1953. Emane took away all the medicines. People say that Zembote did all that. If Zembote hadn't brought Emane and if he hadn't sent Essia away, none of this would have happened.

Nze here evokes occult agency, that is, 'representations that heavily emphasize human actions but that, at the same time, hide the actors and their acts from view' (Geschiere 1997: 22). In the realm of politics, secrecy and power, the apparent and the concealed are always related (Eaton 2006). Moreover, human intentions always lurk behind cases of political misfortune. Zembote's complicity in the mysterious death of his political rival remained concealed, or only vaguely suspected, until he brought Emane to Ogooué-Ivindo to protect himself.

\section{'AND THEY CALL HER MADEMOISELLE ...'}

Fang villagers in the region linked Emane's anti-fetish tour even more directly to Essia-Nsomore's death. In response to a question about Emane, a village chief, accompanied by the Parti Démocratique Gabonais (PDG) village committee president, immediately made the political connection. ${ }^{25}$ The chief also placed the former chef de canton, Menie-M'Oyone Fabien, at the centre of the affair. Menie, born in $c$. 1909, served in the French military from 1929 to 1944, rising to the rank of master sergeant. Upon his return home, Menie took a leading role in the clan

NE 7, District de MKK, 'Bulletin d'informations politiques, Juillet 1952', N. Sanquer). The 1952 Annual Political Report suggests that the colonial administration favoured Zembote, who was clearly the weaker candidate, but expressed reservations about Essia's 'fairly strong (assez forte) personality'.

In any case, the 'weaker' candidate's election allowed the Chef de District (M. Sanquer) to retain firm, paternalistic control over his district. He writes: Zembote 'is blamed for the failure of Essia for having made a common list with the Dambomo Kemane.... He has not received and will not receive the unanimous adherence of the population. He knows that his position is difficult, and expends considerable effort to win the people's confidence. He attends to the requests that are made of him, and comes to discuss them with the District Chief. He would like to act, but is incapable because he is incompetent. He operates within the limits of his attributes' (ANG, Répertoire Makokou, Carton No. 7).

${ }^{24}$ Nze also noted that Efa-Ayong Edouard, a nurse, Essia's lieutenant in the 1952 elections, had also died in 1953.

${ }^{25}$ Because of the sensitive comments in this interview, I do not identify the speakers by name or village. 
reunification movement, the rewriting of 'clan' history, the Mimbiri religion, and local politics. He was a trusted auxiliary of the colonial administration and, after independence, of presidents Léon Mba and Omar Bongo. Menie served as canton chief from 1952 until his death in 1982 (Ntoule-Akame n.d.; Cinnamon 1998). ${ }^{26}$ As these village elders saw it, Menie and Emane shaped late-colonial local and regional politics, set against the backdrop of emerging nationalist politics:

Chief: Emane Nyangone came to do his business. We were here. Essia-Nsomore died. He was for us, something great ... for paper [izangu]. [He was an intellectual, a man of book learning.] This was an enormous affair. Essia's running mate also died. So, everyone was surprised, and said, 'Oh! Menie-M'Oyone and those people have managed to kill our two Fang 'heads' [mìnlú mí Fay, 'intellectuals', also 'leaders'].

Committee President: After the death of Essia-Nsomore, Zembote said, 'No, EssiaNsomore is dead, and the Fang say that I'm the one who killed him. They are liable to kill me.' That's when he invited Emane. ... 'The Fang ayon [group]-I'm going to remove [their force].'27

For the chief, Emane's visit stemmed directly from the loss of their two leading intellectuals. Had not these mysterious deaths undermined regional political life at a crucial moment of opportunity? The chief also suggested that the influential canton chief, Menie-M'Oyone, had played a role in the affair. Other sources note Menie's close ties to Zembote. ${ }^{28}$ Had they somehow colluded in Essia's death?

Apparently the chief voiced more widely held, but sensitive, speculations about Menie's involvement. ${ }^{29}$ The late Bifele Alphonse, from Mayiga, also noted that Menie was close to Zembote. Menie and Essia were ambitious men and rivals from the same village, so they did not get along. And as Peter Geschiere (1997) notes, Cameroonian political elites were thought to use occult means to settle their political scores. Had Menie sold out a local rival to side with an 'outsider' from across the river? Or, as an astute and opportunistic political entrepreneur, had he simply sought to profit from the passage of Emane Boncoeur? Menie's own extraordinary success in local politics and wealth accumulation may have convinced people, especially his enemies, that he too had access to invisible force. 'But,' Bifele concluded, 'these are affairs that people suppose. On this earth, no one knows exactly what happened.' 30

Emane-Ebome Raymond (not related to Emane Boncoeur) was cantonal secretary in the mid-1950s and had accompanied Emane's delegation all the way

\footnotetext{
${ }^{26}$ Menie's biography also underlines important connections between occult power and the political imagination (Ntoule-Akame n.d.).

${ }^{27}$ Although the chief and committee president suspected these earlier politicians of occult activity, they themselves were hardly immune from suspicion. The daughter of one of the two, who herself had suffered from bouts of mental illness (crises de folie) and who had been eventually healed by Ndéndé's sister who worked with Mimbare, accused both the chief and committee president of having provoked her own illness and of being the biggest sorcerers in the village.

${ }^{28}$ Ntoule-Akame Léon, 'La vie et son temps' (Manuscript biography of Menie M'Oyone Fabien).

${ }^{29}$ This would fit local notions of sorcery, in which victims had to be close kin or affines. Menie would have been in a good position to find someone close to Essia for the necessary betrayal. $\mathrm{He}$ provides part of the 'missing link' between Zembote and Essia.

${ }^{30}$ Bifele-Bi-Yigha Alphonse, Interview, Mayiga, 11 April 1990.
} 
to Mintoum, where Emane (the healer) stopped. He also mentioned the 'Zembote-Essia affair' and observed, 'Zembote and Menie were supposed to be together. Menie feared medicines. Emane Boncoeur said that he had come to remove medicines, [but] he wanted to take away the fétiches from the others without removing theirs' - that is, Menie's and Zembote's. ${ }^{31}$ Here, Emane (the healer) emerges as an accomplice in regional politicians' designs to accumulate invisible forces while nullifying those of their constituents and rivals. EmaneEbome expressed two widely held sentiments: first, ritual experts frequently operate as double agents who use invisible force to strengthen some and weaken others. Second, political elites deliberately set out to enhance their hold on power by weakening that of the population - economically, politically, and in the realm of the invisible. In this sense, Emane's passage set the tone for subsequent interaction between villagers and those who would inherit state power, the latter comprising a trans-ethnic alliance of elites against the people. Emane-Ebome, who later became a registered nurse, also observed that a deadly flu epidemic spread through the region after the departure of Emane. This was interpreted as the wrath of Mademoiselle and Mimbare-or as an expression of new powerlessness after the removal of medicines and protections.

Not everyone, of course, interpreted the arrival of Emane as a political event, especially on the opposite side of the Ivindo. Joseph Bapasse, Kwélé from Abord, for example, downplayed the political and ethnic dimension of Emane's expedition: 'For us Emane-Boncoeur did not come because of the Fang. We didn't want him to visit all the cantons. The government wanted him to go to all the cantons. They obliged [the canton chiefs] Menie and Njolé to sign. ... They speak about politics now. It wasn't politics. The Bakwélé didn't do politics.' ${ }^{32}$ Contrasting interpretations aside, diverse actors involved nonetheless shared a common political imaginary in which sorcery/anti-sorcery was linked, one way or another, to state power. While Bapasse denied the political dimension of Emane's journey, he did acknowledge active government interest.

It was risky, of course, to accuse Menie of having colluded in Essia's death; such accusations could dredge up submerged conflicts on the Fang side of the Ivindo. In the above-cited interview, as soon as the village chief mentioned Menie's name, the committee president interrupted him, re-focusing suspicion on the politically safer outsider, Zembote. The chief quickly concurred. At that point, discussion took on an ethnic dimension (Zembote the Kwélé vs the Fang). ${ }^{33}$ To protect himself and escape retribution, Zembote now had to neutralize or 'remove' the entire Fang group (ayon). He called Emane from Souanké so that Emane could 'slaughter' the Fang sorcerers to prevent them from retaliating, while weakening the ayon:

Chief: When Emane Nyangone arrived, he slaughtered [atsip, lit. 'to kill abundantly at hunting or fishing'] a lot of people. He didn't kill people with a gun; he killed those

\footnotetext{
${ }^{31}$ Emane-Ebome Raymond, Interview, Mayiga, 6 April 1990.

${ }^{32}$ Joseph Bapasse, Interview, Libreville, June 1996. Bapasse's version of Emane's passage deemphasizes the political dimension, but, like other accounts both political and apolitical, admits that afterwards the Kwélé remained in a weakened albeit purified state.

${ }^{33} \mathrm{In}$ his interview, Zembote had sought to dispel such claims by claiming that he was 'Bakwélé, Fang, and Bakota'.
} 
who went out in vampirism [ngbal]. Emane removed the mabyan from Makokou to the limit of Mintoum.

For three nights Emane was here struggling.... He pointed to people and said, 'You, you have mabyan. Remove them.' So, I remove them. [Even] women in the kitchen.... Another man present: He didn't skip any villages.

The source of Emane's power was, of course, Mimbare and Mademoiselle. The chief suggested that Mademoiselle was especially powerful, because she was white [ntaja], which evoked both Europeans and the ancestors. ${ }^{34}$ As in the other versions, although Mademoiselle attacked sorcerers, she, too, was a killer:

Chief: Can I know Mademoiselle? Mademoiselle was mabyan. His [Emane's] magic [Fr. magie] was called Mademoiselle. The people who saw her, saw her as white. Do you understand? It is she who kills people even today. For example, a sorcerer [nnəm] says, 'As my friend is sitting here, I decide that I am going to eat him.' ${ }^{35}$ [That night], I go out - Buиuи! - I die. And they call her Mademoiselle.

\section{THE PATHS OF POLITICS (MӘNZӘN MӘ YA POLITIQUE)}

A central argument here is that the passage of Emane and his spirits must be considered in relation to the emergence of a regional and national political imagination in north-eastern Gabon. This imagination is informed in part by ethnicity. In Ogooué-Ivindo since the 1950s, ambitious Kota-, Bekwil-, Fang-, and Shakè-speaking politicians from the region have vied for regional and national political office and power. At the same time, the political alliance between Menie (a Fang) and Zembote (a Kwélé), and the fact that both Emane and his spirits traversed ethnic and even national boundaries suggest that the politics of ethnicity was never clear-cut.

In this section I trace connections between regional politics and the birth of national politics in the 1950s. In the minds of many Ogooué-Ivindo Fang speakers, the loss of Essia-Nsomore, followed by the Emane's officially sanctioned anti-fetish campaign, foreshadowed Jean-Hilaire Aubame's later defeat by Léon M'Ba. One village that Emane visited in 1955 was a recent regroupement west of Makokou on the road to Ovan. When Zembote had won the Territorial Assembly election in 1952, this regroupement village did not yet exist; its future inhabitants still lived in a number of smaller villages on the old Ndzong Angouma road north of the main road. They did not vote and had been only vaguely aware of the elections. Their 1953 move out of the forest at the behest of the colonial administration brought them closer to government authority, surveillance and politics. For many, the move, while leading to greater

\footnotetext{
${ }^{34}$ Guyer and Belinga (1995: 118) discuss the meaning of the term 'ntana': 'This is the only region in Africa, to our knowledge, where the term for Europeans referred to intellectual characteristics rather than physical ones: the people who could count and recount.' Although the term does not refer to colour, Europeans are connected to ancestors: Mademoiselle is therefore linked to both.

${ }^{35}$ As elsewhere, eating refers here to the consuming of victims' life force and is tied to a cluster of concepts linked to the eating of power and money by political elites.
} 
opportunities for schooling and health care, also brought a growing sense of dependency, marginalization and frustration that has characterized the villagers' dealings with the Gabonese state for the past half-century. Stories of Emane's journey narrate both the beginnings of politics and the roots of political marginalization.

In a 1991 interview, Nzeng Jean, an elder from this regroupement, spoke of multiple political beginnings, betrayed hopes, and his village's highly ambiguous interactions with the Gabonese state. Nzeng meditated on Zembote, Essia and Emane; his people's move to the road; their loyalty to Jean-Hilaire Aubame; and their strained relationship with Gabon's first president, Léon M'Ba. Nzeng revealed himself as an astute observer of Gabonese national politics. He had listened intently and critically over the years to politicians and authorities. Acutely aware of the power dynamics in Gabon's political landscape, he measured promises and propaganda against lived experience, unfulfilled expectation, official neglect and state oppression.

Nzeng traced the 'origin of politics' to the late-colonial liberalization of the 1950s. ${ }^{36} \mathrm{He}$ identified multiple political beginnings, including the Zembote-EssiaNsomore affair, which had unfolded before his people had relocated to the main road:

There is the beginning of la politique.... When they did the vote, we were still at Ndzong Angouma.... We didn't see them. We only heard that they campaigned in Makokou. We came to find Zembote as chief [ndzui], at our arrival in the new village [məvan] here.

... We didn't do the vote of Zembote. ... It was the beginning of the députés.

Nzeng also referred to Essia-Nsomore's death and Zembote's role in bringing Emane. 'We were surprised to learn that Essia-Nsomore died,' he said. 'We only came to know it when Zembote went to get Emane. Then I saw the Fang burning with shame.' According to Nzeng, it was only when Emane Nyangone arrived that they concluded that Zembote had killed Essia-Nsomore. Otherwise, why would he have called Emane?

But it was not only through Zembote's dubious triumph that the regroupement's future residents learned of politics. While still at Ndzong Angouma, they had also begun to hear the name of Aubame-Eyeghe, or Jean-Hilaire Aubame. Nzeng explained, 'We started to know [politics], because they came to tell us, "Accept Aubame ... accept Aubame-Eyeghe." So we said, "He's the person that we'll accept." Aubame remained a leading political figure in post-war Gabon and the chief political rival of Gabon's first President, Léon M'Ba. He was also an architect of the village regroupement policy that sought to combine atomized villages of the Gabonese countryside in order to facilitate the construction of schools, dispensaries and other modern innovations. ${ }^{37}$ As noted above, Nzeng's regroupement itself was a product of Aubame's policy and administrative convenience. By 1951, Aubame and his party had won virtually unanimous

\footnotetext{
${ }^{36}$ Another elder from Makokou had spoken of the 'old politics', linked to iron metallurgy, trade, wealth, knowledge and truth. In his discussion of leadership, this elder told the story of a ruse used to lure an enemy big man into a trap during a feud. Gabriel Nze Assé, Interview, Libreville, 4 August 1990.

${ }^{37}$ See Pourtier (1989: 107) for a summary of Aubame's regroupement programme.
} 
support among Ogooué-Ivindo Fang speakers. ${ }^{38}$ Like Essia-Nsomore, Aubame remains firmly rooted in popular political consciousness, in part as a symbol of frustrated hopes.

Politics had thus begun while they were still at Ndzong Angouma, but began again (or truly began) with the move to the main road. Nzeng says: 'When we came from Ndzong Angouma to arrive here at the main road [nkpax], it was then that the affair [dzám] of politics broke out.' These were, as Nzeng puts it, 'affairs of here'. Yet another beginning of politics came when Léon M'Ba took over 'commandement' from the whites at the end of the 1950s:

When the white commandants had left, it was then that politics began. At that time, both the white commandant and the black commandant stayed here. When the whites had left, it was the turn of the blacks. It was at that time that we knew what politics were. Politics began when Léon M'Ba took commandement. That was the beginning of politics.

Once they had settled on the main road, the people of the regroupement began to receive occasional visits from political leaders on tour from Libreville. Their new leaders spoke of coming independence, telling them that they were separating from the whites in order to take command of the country. Looking back on this period, Nzeng made a number of contradictory observations. He expressed pleasure at partial separation from the French, hope in Gabon's new leaders, and the inevitable disillusionment that followed unfulfilled promises. His words reflected his own understandings of the intersection of the local, the national and the transnational:

We work because they told us, 'This is your country.' That's why we accepted the affair of politique. [But this resulted in the] disorder [inzonzam] that they [the politicians] are doing to us at present.

And we also saw that as we've taken politics, we thought we were going to see justice in life. When the blacks took the country, we saw that as good ... because we had seen much harassment. But it was an even worse evil that we still have to the present. So, this is what we have known of politics....

This work of Aubame saved us and made us well [mvoghe]. Then we said that politics is good work. ... He showed us the paths of politics [menzən ma ya politique].... It was then that we knew politics.

Somehow, the French député, Jean-Hilaire Aubame, had convinced the villagers of this 'poor',' 'isolated', demographically 'mediocre' region (Balandier 1982 [1955]: 95) that his politics would, as Nzeng put it, 'help all of us'. Villagers may have seen the proposed benefits of his regroupement programme-including schools, dispensaries, and economic opportunities - as paths toward modernity. ${ }^{39}$

\footnotetext{
${ }^{38}$ In the 1951 legislative elections, 1,050 persons voted in Makokou District: 'en masse for J. H. AUBAME ( 785 votes) (all Fang and some Bakwélé); Louis BIGMANN received 244 votes from Bakotas. Léon M'Ba received only 7 votes.' See 'Région de l'Ogooué-Ivindo, District de MKK, Bulletin d'informations politiques, Mai-Juin 1951', J. Gassmann. In ANG, Répertoire MKK. Carton No. 7, 1951.

${ }^{39}$ Writing in the 1950s, Balandier (1982 [1955]: 85) depicted the Ogooué-Ivindo as 'one of the poorest regions in Gabon', but also noted 'the avidity with which all innovations that it was hoped would bring a better life were welcomed'.
} 
Aubame's message and bearing evidently appealed to villagers' openness to new opportunities and strategies for social success. As Nzeng's remarks suggest, Aubame, like Essia-Nsomore, continues to occupy an important place in the popular political imagination.

When it came to the rivalry between Léon Mba and Aubame, Nzeng said, 'Above all, the people of the village liked Aubame-Eyeghe. ... [We] refused the habits of Léon M'Ba.' In Nzeng's eyes, Aubame-Eyeghe, rather than Léon M'Ba, had liberated the country. 'This is why we liked Aubame-Eyeghe ... every person turned to the party [ngam] of Aubame-Eyeghe [the USDG].'

Nzeng's interpretation underlines widespread ambivalence over Gabon's special ties to France. He portrayed Aubame as the means by which the Gabonese would maintain access to the French technical expertise needed for the production of necessary 'modern' commodities. In fact, both Aubame and M'Ba had very close relations with the French government. Although M'Ba flirted with communism in the late 1940s, he soon learned that the path to power in Gabon required the support of French administrators and businessmen. By the late 1950s administrative backing had shifted decisively from Aubame to Léon M'Ba (Bernault 1996). In Ogooué-Ivindo, the administration actively campaigned to convert chiefs, politicians, and, with less success, the general population. Aubame may have displayed too much economic nationalism and commitment to participatory democracy. Once M'Ba rose to power in 1957, he, with the help of the administration, attempted to weaken and co-opt his opposition (including Aubame)-subordinating them after 1961 to a strong presidential regime, which persists to the present.

As at least some Fang-speaking villagers saw it, the multiple beginnings of politics in the 1950s - the rivalry between Nzembote and Essia-Nsomore, the passage of Emane Nyangone and Mademoiselle, and the eventual triumph of Léon M'Ba over Jean-Hilaire Aubame - set the tone for the paths of politics in the post-colonial period. Fang speakers themselves remained loyal to the opposition candidates they thought would best serve their interests. Later, they gave strong support to the Paul Mba-Abessole, who served as a Roman Catholic priest in Makokou from 1969 to 1973 until he was forced to flee (with villagers' complicity) for challenging President Bongo's single-party regime. Most OgoouéIvindo Fang speakers remained loyal to Mba-Abessole, who emerged as the leading opposition figure in the multi-party Gabon of the 1990s, before he eventually rallied to the presidential majority and accepted a post as a government minister. ${ }^{40}$

\section{CONCLUSION}

The passage of Emane and his spirits through the Fang-speaking villages of Ogooué-Ivindo constitutes perhaps the most overtly political chapter in the

\footnotetext{
${ }^{40} \mathrm{By}$ the end of the 1990 s, Mba-Abessole had rallied the presidential majority. In 2002, he joined the government as a minister. Following Omar Bongo Ondimba's death in June 2009, Mba-Abessole gave up his ministerial post and joined the main opposition coalition in the September 2009 presidential elections.
} 
long careers of Mademoiselle and Mimbare. Such political appropriation of white spirits was not unprecedented in French colonial Africa. Paul Stoller (1989; 1995), for example, has noted how Hauka spirits, exhibiting extravagantly exaggerated qualities of Europeans, burst upon the scene among the Songhay in Niger during the 1920s. These spirits allowed mediums to use European power to oppose European colonial rule. Even in the post-colony, "[t]he "force" of the European continues to be strong in all regions of the Republic of Niger; the need for many to make sense of this "force" remains equally strong' (1989: 161).

In the Gabonese case, rather than constituting a site of resistance to white power, Mademoiselle and Mimbare actualized a form of white power that reinforced ritual experts, their patrons and clients, and the late-colonial government while undermining other Africans and African knowledge. Stories of Mademoiselle and Mimbare provide Fang speakers in north-eastern Gabon with one way to make sense of the transition from colonial rule to the paths of politics. Regional political marginalization resulted from mystical political agency and local chains of causality. An intra-village rivalry (between Menie and Essia) informed a regional political rivalry (between Essia and Zembote) resulting, at least as some people imagine it, in long-term consequences for the region. As suggested above, the affair between Essia and Zembote prefigured the national rivalry between Jean-Hilaire Aubame and Léon M'Ba, and, later, between Paul Mba-Abessole and Omar Bongo. ${ }^{41}$

Although Mademoiselle and Mimbare were not as directly implicated in politics elsewhere in Gabon, they do point to longue-durée associations between invisible powers and political power in equatorial Africa (Vansina 1990: 95-9; MacGaffey 2000; Thornton 1998, 2003). Writing on the Bëti of Cameroon, Laburthe-Tolra (1985: 99) argues that évu-the 'vital dynamism' that resides in the bodies of individuals and from which derives 'all power, wealth or success' - is old, historical, and modern. Laburthe finds évu 'one of the strongest constants of Bëti culture, a constant in which the vicissitudes of history play a leading role' (1985: 60). As he puts it: 'Evú seems to constitute power par excellence ... evú is intimately tied to the exercise of political power, and the mystery that surrounds it is perhaps an integral part of the permanent conspiracy of politicians to monopolize it' (Laburthe-Tolra 1985: 95)..$^{42}$

Moreover, Mademoiselle, along with the widespread presence of Mami Wata across West and Central Africa (see Drewal 2008), suggests that transnational imaginaries inform cross-cultural relations of power more broadly. Mademoiselle exemplifies a particularly vivid way of imagining and striving to harness external sources of power. As a white spirit arriving in rural (and later urban) Congo and Gabon from Europe, Mademoiselle indeed embodies rupture and hybridity, but

\footnotetext{
${ }^{41}$ Even among Ogooué-Ivindo Fang speakers, the roles of these spirits became less overtly political. Emane's most prominent Fang-speaking successor, Minko-Mi-Nzoghe, incorporated the spirits into the Mimbiri healing religion. Yet even he became a political adviser and operator of sorts. Minko treated and counselled political big men (including, by some accounts, the late President Bongo) who sought to protect and advance themselves in the national arena. At least until Minko's death in 1998, Mademoiselle and Mimbare thus remained linked to the political imagination in north-eastern Gabon.

${ }^{42}$ Recent work by Florence Bernault (2006, 2009a, 2009b) has attempted to trace shifts in equatorial African imaginaries since the onset of the colonial period.
} 
also continuities. She draws on well-established but shifting realms of spirits, ancestors, whiteness, 'fetishes' and anti-sorcery movements whose content and values had nonetheless changed under colonial rule (Bernault 2006; 2009a). At the same time, it is possible to see Mademoiselle and Mimbare as 'border fetishes' - the product of 'the cultural, commercial, and political crossings that characterize fetish formations' (Spyer 1998: 1). As these spirits/fetishes crossed over from Europe to Cameroon, Moyen-Congo, Gabon and beyond, from the invisible to the visible, from the realm of the dead to that of the living, from the local to the national, from colonialism to independence, from white to African, from 'regimes of fetish' to 'symbolic uncertainty' (Bernault 2009a), from African spirituality to Christianity, they unsettled borders and confounded 'neat resolutions and clear-cut boundaries among things and between persons and objects' (Spyer 1998: 2-3). ${ }^{43}$

This leads back to the centrality of invisible force in the political imagination. The intent here is not to reduce politics to sorcery discourses. Indeed, as I have endeavoured to show, Fang elders are eminently capable of narrating regional and national political history both with and without attribution of occult agency. Nonetheless, the invisible remains a key means by which both political elites and villagers struggle over and represent state power. By this logic, the most powerful politicians are considered to have hired the most powerful ngangas and sorcerers - or to be sorcerers themselves. In the late 1980s, a successful accountant from Makokou was reluctant to enter the political fray, because, he said, 'To do politics, you must kill.' 44

The narratives presented here form a locally constructed story of political marginalization, disempowerment, and aborted potential. In a decisive moment of opportunity, a leading political contender was knocked out of the political arena by an 'inferior' rival who then sold people out to the forces of Mademoiselle and Mimbare. No one expressed this lost potential better than Nze ThomasDydyme, whose own topsy-turvy political career exemplified the vicissitudes of Gabonese political life and the tensions between the Ogooué-Ivindo region and the Gabonese state:

For the people of our region, if Essia had been elected in 1952, we say that he would have been better for Makokou than Zembote. Zembote didn't have his Primary School Certificate. ${ }^{45} \mathrm{He}$ couldn't deal with the likes of Jean-Hilaire Aubame or Léon M'Ba. Zembote was far from them. If Essia had been elected, he would have been like them. The people believe that Zembote was responsible for their backwardness [retard]. Others went to Brazzaville. Essia knew more. He could have represented their interests. ${ }^{46}$

\footnotetext{
${ }^{43}$ Of course, MacGaffey (2000: 12) notes the permeable boundaries between Kongo chiefs, healers and power objects (minkisi). He also points to the interchangeability of spirits (bisimbi), objects, and whites, all of whom derive from the realm of the dead - the ultimate source of power (MacGaffey 1993: 54, 61-62).

${ }^{44}$ This is, of course, a lesson that political leaders around the world, including the United States, have understood all too well.

${ }^{45}$ Zembote himself admitted that he had only attained the level of CP2 (the second year of the primary cycle).

${ }^{46}$ Interview, Nze-Emane Thomas-Dydyme, Libreville, 24 June 1995.
} 
Finally, the story of Mademoiselle contains powerful expressions of political powerlessness and exclusion from state politics that proclaim regional political identity. When the village chief said, 'We lost our leading intellectual', he was making a statement of identity, explaining why his people had remained on the outside looking in. As he saw it, his people have been betrayed, from the very beginning, by their own elites, who have used both occult and anti-occult forces to further their political careers while preying on their constituents. In this sense, these stories of powerlessness and marginalization contain the elements of a potent political critique. At the same time, their use by Nze Thomas-Dydyme, once himself an ambitious member of the political elite with scant popular support back home in Makokou, only underscores the ambiguities of the relations between the invisible and state power.

\section{REFERENCES}

Apter, A. (1993) 'Atinga revisited: Yoruba witchcraft and the cocoa economy, 1950-1951' in J. and J. L. Comaroff (eds), Modernity and Its Malcontents: ritual and power in postcolonial Africa. Chicago IL: University of Chicago Press.

Ashforth, A. (2005) Witchcraft, Violence, and Democracy in South Africa. Chicago IL: University of Chicago Press.

Aubame, J.-M. (2002) Les Beti du Gabon et d'ailleurs: Tome 2, Croyances, us et coutumes. Paris: L'Harmattan.

Balandier, G. (1982) [1955] La sociologie actuelle de l'Afrique noire: dynamique sociale en Afrique centrale, fourth edition. Paris: Presses Universitaires de France.

Bayart, J.-F. (2005) [1996] The Illusion of Cultural Identity, translated by S. Rendall, J. Roitman, C. Schoch, and J. Derrick. Chicago IL: University of Chicago Press.

Bernault, F. (1996) Démocraties ambiguës en Afrique Centrale: CongoBrazzaville, Gabon, 1940-1965. Paris: Karthala.

- (2006) 'Body, power and sacrifice in Equatorial Africa', Journal of African History 47 (2): 207-39.

- (2009a) 'La chair et son secret: transfiguration du fétiche et incertitude symbolique au sud-Gabon', Politique africaine 115: 99-122.

— (2009b) 'De la modernité comme impuissance: fétichisme et crise du politique en Afrique équatoriale et ailleurs', Cahiers d'études africaines 3 (195): 747-74.

Brennan, J. R. (2006) 'Blood enemies: exploitation and urban citizenship in the nationalist political thought of Tanzania, 1958-1975', Journal of African History 47 (3): 387-411.

(2008) 'Destroying Mumiani: cause, context and violence in late colonial Dar es Salaam', Journal of Eastern African Studies 2 (1): 95-111.

Cinnamon, J. M. (1998) 'The Long March of the Fang: anthropology and history in Equatorial Africa'. PhD thesis, Yale University.

(2002) 'Ambivalent power: anti-sorcery and occult subjugation in late colonial Gabon', Journal of Colonialism and Colonial History 3 (3). 
Comaroff, J. and J. L. Comaroff (1999) 'Occult economies and the violence of abstraction: notes from the South African postcolony', American Ethnologist 26 (2): 279-303.

(2000) 'Millennial capitalism: first thoughts on a second coming', Public Culture 12 (2): 291-343.

Crais, C. (1998) 'Of men, magic, and the law: popular justice and the political imagination in South Africa', Journal of Social History 32 (1): 49-72.

_ (2002) The Politics of Evil: magic, state power, and the political imagination in South Africa. Cambridge: Cambridge University Press.

Digo, Y. (Gouverneur, Chef du Territoire du Gabon) (1956) 'Note sur le mouvement de contre-fétichisme et le fétiche "Mademoiselle", au Gabon', Archives Nationales, Libreville, Afrique Equatoriale Française, Territoire du Gabon, Dossier Mitzic, 19 October.

Drewal, H. J. (2008) 'Introduction: charting the voyage' in H. J. Drewal (ed.), Sacred Waters: arts for Mami Wata and other divinities in Africa and the diaspora. Bloomington IN: Indiana University Press.

Eaton, D. (2006) 'Diagnosing the crisis in the Republic of Congo', Africa 76 (1): 44-69.

Ellis, S. and G. Ter Haar (2004) Worlds of Power: religious thought and political practice in Africa. New York NY: Oxford University Press.

Fernandez, J. (1982) Bwiti: an ethnography of the religious imagination in Africa. Princeton NJ: Princeton University Press.

Geiger, S. (1996) 'Tanganyikan nationalism as "women's work": life histories, collective biography and changing historiography', Journal of African History 37 (3): 465-78.

- (1997) TANU Women: gender and culture in the making of Tanganyikan nationalism, 1955-1965. Portsmouth NH: Heinemann.

Geschiere, P. (1982) Village Communities and the State: changing relations among the Maka of south-eastern Cameroon since the colonial conquest. London: Kegan Paul.

- (1997) The Modernity of Witchcraft: politics and the occult in postcolonial Africa. Charlottesville VA: University Press of Virginia.

Guyer, J. and S. M. E. Belinga (1995) 'Wealth in people as wealth in knowledge: accumulation and composition in Equatorial Africa', Journal of African History 36 (1): 91-120.

Hagenbucher-Sacripanti, F. (1992) Santé et redemption par les genies au Congo, second edition. Paris: Publisud.

- (2002) Le prophète et le militant, Congo-Brazzaville: histoires de vie, discours des génies. Paris: L’Harmattan.

Hersak, D. (2001) 'There are many Kongo worlds: particularities of magicoreligious beliefs among the Vili and Yombe of Congo-Brazzaville', Africa 71 (4): 614-40.

Kirsch, T. (2008) Spirits and Letters: reading, writing, and charisma in African spirituality. New York NY: Berghan Books.

Laburthe-Tolra, P. (1985) Initiations et sociétés secrètes au Cameroun: essai sur la réligion Bëti. Paris: Karthala.

MacGaffey, W. (1993) 'The eyes of understanding: Kongo Minkisi' in Astonishment and Power. Washington DC: National Museum of African Art/ Smithsonian Institution Press. 
(2000) Kongo Political Culture: the conceptual challenge of the particular. Bloomington IN: Indiana University Press.

Masquelier, A. (2001) 'Behind the dispensary's prosperous façade: imagining the state in rural Niger', Public Culture 13 (2): 267-91.

Maxwell, D. (2006) African Gifts of the Spirit: Pentecostalism and the rise of a Zimbabwean transnational religious movement. Oxford: James Currey.

Mba Ndzeng L. (2006) “Para-societe” et pouvoir politique au Gabon'. PhD thesis, University of Paris V.

Mbembe, A. (2001) On the Postcolony. Berkeley CA: University of California Press.

Moorman, M. J. (2008) Intonations: a social history of music and nation in Luanda, Angola from 1945 to recent times. Athens OH: Ohio University Press.

Ngolet, F. (2000) 'Ideological manipulations and political longevity: the power of Omar Bongo in Gabon since 1967', African Studies Review 43 (2): 55-71.

Niehaus, I. A. (2001) Witchcraft, Power, and Politics: exploring the occult in the South African lowveld. London: Pluto Press.

Ntoule-Akame, L. (n.d.) 'La vie et son temps', unpublished manuscript biography of Menie-M'Oyone Fabien.

Pietz, W. (1985) 'The problem of the fetish, Part 1', RES: Anthropology and Aesthetics 9: 5-17.

(1987) 'The problem of the fetish, Part 2: The origin of the fetish', RES: Anthropology and Aesthetics 13: 23-45.

(1988) 'The problem of the fetish, Part 3a: Bosman's Guinea and the enlightenment theory of fetishism', RES: Anthropology and Aesthetics, 16: 105-23.

Pourtier, R. (1989) Le Gabon, Tome 2: État et développement. Paris: L'Harmattan.

Ranger, T. (2007) 'Scotland Yard in the bush: medicine murders, child witches and the construction of the occult: a literature review', Africa 77 (2): 272-83.

Schatzberg, M. G. (2001) Political Legitimacy in Middle Africa: father, family, food. Bloomington IN : Indiana University Press.

Schmidt, E. (2005) Mobilizing the Masses: gender, ethnicity, and class in the nationalist movement in Guinea, 1939-1958. Portsmouth NH: Heinemann.

_ (2009) 'Anticolonial nationalism in French West Africa: what made Guinea unique?', African Studies Review 52 (2): 1-34.

Soret, M. (1959) Les Kongo nord-occidentaux (avec la collaboration d'André Jacquot pour les questions de linguistique). Paris: Presses Universitaires de France.

Spyer, P. (1998) 'Introduction' in P. Spyer (ed.), Border Fetishisms: material objects in unstable spaces. New York NY: Routledge.

Stoller, P. (1989) Fusion of the Worlds: an ethnography of possession among the Songhay of Niger. Chicago IL: University of Chicago Press.

— (1995) Embodying Colonial Memories: spirit possession, power, and the Hauka in West Africa. Chicago IL: University of Chicago Press.

Terretta, M. (2005) "'God of peace, God of independence": village nationalism in the Maquis of Cameroun, 1957-1971', Journal of African History 46 (1): 75-101. 
Thornton, J. K. (1998) The Kongolese Saint Anthony: Dona Beatriz Kimpa Vita and the Antonian Movement, 1684-1706. Cambridge and New York NY: Cambridge University Press.

(2003) 'Cannibals, witches, and slave traders in the Atlantic world', William and Mary Quarterly 60 (2): 273-94.

Tobia-Chadeisson, M. (2002) Le fétiche africain: chronique d'un 'malentendu'. Paris: L'Harmattan.

Tonda, J. (2000) 'Capital sorcier et travail de Dieu', Politique africaine 79: 48-65. (2002) La Guérison divine en Afrique Centrale (Congo, Gabon). Paris: Karthala.

(2005) Le Souvereign moderne: le corps du pouvoir en Afrique centrale (Congo, Gabon). Paris: Karthala.

Vansina, J. (1990) Paths in the Rain Forest. Madison WI: University of Wisconsin Press.

Weinstein, B. (1966) Gabon: nation-building on the Ogooué. Cambridge MA: MIT Press.

West, H. G. (2005) Kupilikula: governance and the invisible realm in Mozambique. Chicago IL: University of Chicago Press.

\begin{abstract}
Through narratives of an anti-'fetish' movement that swept through north-eastern Gabon in the mid-1950s, the present article traces the contours of converging political and religious imaginations in that country in the years preceding independence. Fang speakers in the region make explicit connections between the arrival of post-Second World War electoral politics, the anti-fetish movements, and perceptions of political weakening and marginalization of their region on the eve of independence. Rival politicians and the colonial administration played key roles in the movement, which brought in a Congolese ritual expert, Emane Boncoeur, and his two powerful spirits, Mademoiselle and Mimbare. These spirits, later recuperated in a wide range of healing practices, continue to operate today throughout northern Gabon and Rio Muni. In local imaginaries, these spirits played central roles in the birth of both regional and national politics, paradoxically strengthening the colonial administration and Gabonese auxiliaries in an era of pre-independence liberalization. Thus, regional political events in the 1950s rehearsed later configurations of power, including presidential politics, on the national stage.
\end{abstract}

\title{
RÉSUMÉ
}

À travers les récits d'un mouvement anti-« fétiche » qui s'est propagé rapidement dans le Nord-Est du Gabon dans le milieu des années 1950, cet article trace les contours d'imaginations politiques et religieuses convergentes dans ce pays dans les années qui ont précédé l'indépendance. Les locuteurs fang de la région voient des liens explicites entre l'arrivée de la politique électorale d'après Seconde Guerre mondiale, les mouvements anti-fétiche et les perceptions d'affaiblissement politique et de marginalisation de leur région à la veille de l'indépendance. Les politiciens rivaux et l'administration coloniale ont joué des rôles clés dans ce mouvement qui a fait appel à un spécialiste congolais des rites, Emane Boncoeur, et ses deux puissants esprits, Mademoiselle et Mimbare. Ces esprits, récupérés 
plus tard dans un large éventail de pratiques de guérison, sont toujours présents aujourd'hui dans tout le Nord du Gabon et dans le Rio Muni. Dans les imaginaires locaux, ces esprits ont joué des rôles centraux dans la naissance des politiques régionales et nationales, en renforçant paradoxiquement l'administration coloniale et les auxiliaires gabonais dans une ère de libéralisation préindépendance. Ainsi, les événements politiques régionaux des années 1950 ont servi de répétition aux configurations du pouvoir (y compris la politique présidentielle) apparues plus tard sur la scène nationale. 